\title{
カルシウムアルミネート系骨材による遷移帯の改質効果
}

\author{
伊藤 慎也* 盛岡 実* \\ 伊代田 岳史** 丸山一平***
}

\section{Hydration on Surface of Artificial Calcium Aluminate Aggregates and Its Characteristics}

by

\author{
Shinya ITO*, Minoru MORIOKA*， Takeshi IYODA** and Ippei MARUYAMA***
}

\begin{abstract}
Hydration mechanism of calcium aluminate aggregate was examined. In order to confirm the hydration property of calcium aluminate aggregate, hydrate in the paste specimen which was mixed grinded calcium aluminate aggregate, $\mathrm{Ca}(\mathrm{OH})_{2}$ and water was confirmed by XRD. And also hydrate in the paste which was added $\mathrm{CaCl}_{2}$ to above paste was confirmed. The hydrates in the mortar with calcium aluminate aggregate were confirmed by XRD and TG-DTA, and these hydrates were observed by SEM image. In addition, the hydrates were confirmed by EDS and same examinations were carried out for the mortar with natural sand for comparison. Author confirmed that grinded calcium aluminate powder reacts with $\mathrm{Ca}(\mathrm{OH})_{2}$ which is provided as a cement hydrate and it generates hydrocalumite. Furthermore, there was a property to change to Friedel's salt when a chloride ion acted. When the calcium aluminate is used for mortar as fine aggregate, a hydration was occurred at the aggregate surface and it was confirmed to generate hydrocalumite and hydrogarnet in the aggregate surface section. As a result, the possibility that a transition zone of mortar was modified by using the calcium aluminate aggregate was suggested. In the mortar which after salt water immersion, chloride ion penetration depth of mortar with calcium aluminate aggregate was smaller than ordinary mortar. And the hydrate formed layer was confirmed at the fine aggregate surface and its $\mathrm{Ca} / \mathrm{Al}$ or $\mathrm{Cl} / \mathrm{Al}$ molar ratio was similar to Friedel's salt. And hydrates which $\mathrm{Ca} / \mathrm{Al}$ molar ratio is 1.5 to 2.0 were also confirmed on the surface of calcium aluminate aggregate.
\end{abstract}

\section{Key words:}

Calcium aluminate, Aggregate, Transition zone, Hydrocalumite, Hydrogarnet, Friedel's salt

\section{1 緒言}

コンクリート構造物の塩害対策として, 近年ではカル シウムアルミネートの一種である $\mathrm{CaO} \cdot 2 \mathrm{Al}_{2} \mathrm{O}_{3}$ (以下, $\mathrm{CA}_{2}$ ) を混和材として使用することが注目されている. これは，ポルトランドセメントと混和することにより， セメント水和物である $\mathrm{Ca}(\mathrm{OH})_{2}$ (以下, $\mathrm{CH}$ ) と反応して ハイドロカルマイトを生成し, セメントコンクリート中 に浸入してきた塩化物イオンをフリーデル氏塩として 固定化することで，鉄筋腐食の直接的な原因となる可溶 性塩化物イオンを減少させるとともに，拡散係数を小さ くするものである. すなわち, 硬化体中のセメントペー ス卜部分の改質を目的とした技術といえるものであり， これまでに多くの研究報告がなされている ${ }^{1) ~ 4) . ~}$

一方で，モルタルやコンクリートなどの複合材料の場 合, 骨材とセメントペーストとの間に遷移帯が存在する. 一般的に, 遷移帯は水酸化カルシウムの積層や直径 $50 \mathrm{~nm}$ 以上の粗大な空隙を含むポーラスな脆弱層であり, セメ ントコンクリート中の弱点とされている ${ }^{5)}$. 塩化物イオン
をはじめとする劣化要因の浸入を抑制するためには，ぺ 一スト部分の改質に加え, この遷移帯部分の改質も重要 となる、そこで本研究では，コンクリートの耐久性向上 を目的として, 反応性の骨材による遷移帯の改質を期待 して, カルシウムアルミネートがセメント水和物の $\mathrm{CH}$ と 反応して緻密化することに着目した ${ }^{2)}$. カルシウムアル ミネートを骨材として適用した場合にも，ペーストとの 界面で反応が生じるものと考えた。つまり，カルシウム アルミネート系の骨材は遷移帯の自己改質機能を持つ機 能性骨材となり得ると考えた。 そこで, 本論文では, 塩 化物イオンの浸透抑制効果が期待できるカルシウムアル ミネートを骨材として使用した場合の効果を確認する目 的で, $\mathrm{CaO} \cdot \mathrm{Al}_{2} \mathrm{O}_{3}$ (以下, $\mathrm{CA}$ ）を主成分とする骨材（以 下，CA 骨材）の塩化物イオンの浸透抑制効果を実験的に 確認するともにと，その抑制機構の解明を目的として, CA 骨材自身の水和反応性の検討, および細骨材としてモ ルタルに使用した場合の骨材表面部で起こる遷移帯改質 現象と反応メカニズムの検証を行った.

$\dagger$ 原稿受理 平成28年4月11日 Received Apr.11, 2016 ○2016 The Society of Materials Science, Japan

* デンカ(株) 青海工場 セメント・特混研究部 テ949-0393 系魚川市青海

Cement \& Special cement additives Research Dept. , Omi Plant. ， Omi， Itoigawa 949-0393.

*** 芝浦工業大学 $\bar{T} 135-8548$ 東京都江東区豊洲

Shibaura Institute of Technology， Koto-ku， Tokyo 135-8548.

**** 名古屋大学 $=464-8601$ 名古屋市千種区

Nagoya University, Chikusa-ku, Nagoya 464-8601. 


\section{2 実験概要}

\section{$2 \cdot 1$ 使用材料}

Table 1 に, 本実験に使用した CA 骨材の主要化学成分 および密度を示す．CA 骨材自身の反応性を考察するた め，ペース卜実験においては CA 骨材を予めポッドミル で粉砕して粉末化したものを用い，水酸化カルシウムお よび塩化カルシウムは試薬を用いた.

モルタル実験においては，セメントに普通ポルトラン ドセメント（密度： $3.16 \mathrm{~g} / \mathrm{cm}^{3}$ ) を使用し，細骨材には粉 砕して JIS A 5005 に規定される粒度分布の範囲内となる よう調製した CA 細骨材と，密度が $2.62 \mathrm{~g} / \mathrm{cm}^{3}$ の新潟県 姫川水系の天然川砂（以下，天然砂）を使用した。Fig. 1 に，それぞれの粒度分布を示す。なお，ペースト実験， モルタル実験ともに，練混ぜ水として水道水を使用した

$2 \cdot 2$ 実験項目および実験方法

2・2・1 CA 骨材自身の反応性検証 式（1）および 式（2）に示すハイドロカルマイトとフリーデル氏塩の 生成反応が，CA 骨材を用いた場合でも成り立つかを検 証した. Table2 に示寸配合で CA 骨材の粉末, 試薬の $\mathrm{CH}$ と塩化カルシウム（以下， $\mathrm{CaCl}_{2}$ ) および水を小型のプ ラスチック容器に入れ，攪找混合し，ペースト供試体を 作製した。また，時間の経過に伴う水和生成物の変化を 確認するため, 練混ぜ直後と 3 時間経過後の混合ペース 卜供試体をアセトンに浸漬して水和停止し, 粉末 X 線回 折（XRD）にて水和物を同定した。

$$
\begin{aligned}
\mathrm{CaO} & \cdot \mathrm{Al}_{2} \mathrm{O}_{3}+3 \mathrm{Ca}(\mathrm{OH})_{2}+10 \mathrm{H}_{2} \mathrm{O} \\
& \rightarrow 3 \mathrm{CaO} \cdot \mathrm{Al}_{2} \mathrm{O}_{3} \cdot \mathrm{Ca}(\mathrm{OH})_{2} \cdot 12 \mathrm{H}_{2} \mathrm{O} \\
\mathrm{CaO} & \cdot \mathrm{Al}_{2} \mathrm{O}_{3}+3 \mathrm{Ca}(\mathrm{OH})_{2}+8 \mathrm{H}_{2} \mathrm{O}+2 \mathrm{Cl}^{-} \\
& \rightarrow 3 \mathrm{CaO} \cdot \mathrm{Al}_{2} \mathrm{O}_{3} \cdot \mathrm{CaCl}_{2} \cdot 11 \mathrm{H}_{2} \mathrm{O}
\end{aligned}
$$

$2 \cdot 2 \cdot 2$ 遷移帯改質に関する検証 CA 骨材の使用に よる遷移帯改質メカニズムの検証には，モルタル供試体 を用いた。モルタルの練混ぜには JIS R 5201 に準拠した 容量 5 リットルのモルタルミキサーを使用し，供試体は $4 \mathrm{~cm} \times 4 \mathrm{~cm} \times 16 \mathrm{~cm}$ の角柱供試体とした．いずれも水セメン 卜比（表中は W/C と表記）は $50 \mathrm{mass} \%$ とし，細骨材の 密度が異なる影響を排除する目的で，セメントと細骨材 との比率は体積換算で 3.0 とした.

まず始めに，モルタル内部に生成した水和物を確認す る目的で，材齢 1 日で脱型後， $20^{\circ} \mathrm{C}$ 水中養生した CA 細 骨材を $100 \%$ 使用したモルタル供試体を材齢 3 日，28日 時点で $4 \mathrm{~cm} \times 4 \mathrm{~cm} \times 1 \mathrm{~cm}$ に切断し，乳鉢で粉砕した試料を XRD により水和物の同定を行った，次に，示差熱熱重量 測定装置（TG-DTA）を用いて水和物の定量を行った。

また，遷移帯で CA 骨材とペーストの相互作用によっ て生成する水和物, 寸なわちカルシウムアルミネート水 和物の生成有無確認と，そこに塩化物イオンが作用した

\begin{tabular}{|c|c|c|c|c|c|c|}
\hline \multicolumn{6}{|c|}{ Chemical composition (\%) } & \multirow{2}{*}{$\begin{array}{l}\text { Density } \\
\left(\mathrm{g} / \mathrm{cm}^{3}\right)\end{array}$} \\
\hline $\mathrm{Al}_{2} \mathrm{O}_{3}$ & $\mathrm{CaO}$ & $\mathrm{MgO}$ & $\mathrm{SiO}_{2}$ & $\mathrm{FeO}$ & $\mathrm{S}$ & \\
\hline 55.6 & 31.7 & 4.2 & 4.6 & 0.9 & 0.18 & 2.89 \\
\hline
\end{tabular}
場合の水和物の変化を検証した。材齢 5 ケ月間 $20^{\circ} \mathrm{C}$ 水中 養生したモルタル供試体と, 5 ケ月間の水中養生後, $50^{\circ} \mathrm{C}$
Table1 Chemical and physical properties of CA aggregate.

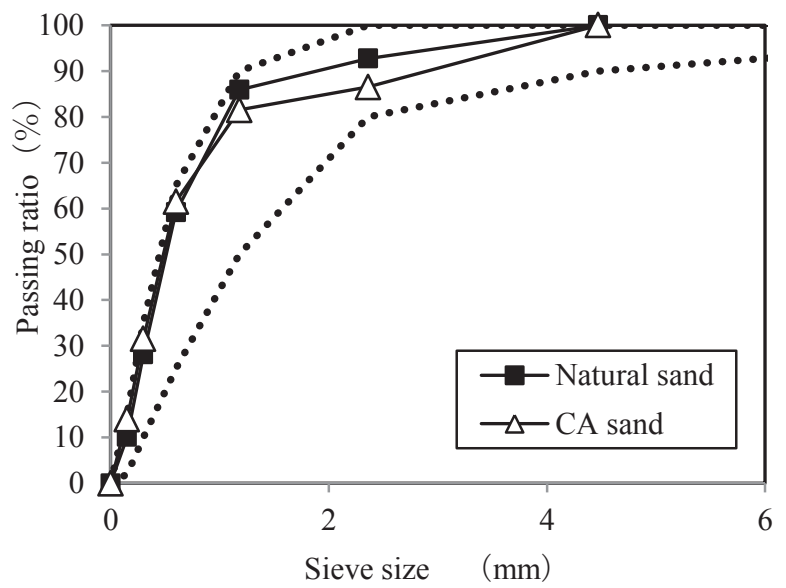

Fig.1 Particle size distribution of sand.

Table2 Mix design of paste.

\begin{tabular}{|c|c|c|c|c|}
\hline \multirow{2}{*}{} & \multicolumn{4}{|c|}{ Weight (g) } \\
\cline { 2 - 5 } & $\begin{array}{c}\text { CA } \\
\text { powder }\end{array}$ & $\mathrm{CH}$ & $\mathrm{CaCl}_{2}$ & Water \\
\hline HCP & 2.08 & 2.92 & - & 5.00 \\
\hline FSP & 1.89 & 1.78 & 1.33 & 5.00 \\
\hline
\end{tabular}

の飽和塩化ナトリウム水溶液に 28 日間浸漬させた（以 下，塩水浸漬）モルタル供試体の両方について供試体を 割裂し, EPMA 画像解析を用いて硬化体内部の元素分布 を確認した。また，割裂断面の骨材部分に着目した反射 電子像の観察と, 元素分析も行った. なお, 反射電子像 の観察には, 走査電子顕微鏡（日立ハイテクノロジー社 製 SEM : SU6600) および微小部元素分析計（オックス フォードInc. 社製 EDS : INCA Energy X-act）を用いた。

\section{3 実験結果と考察}

\section{$3 \cdot 1 \mathrm{CA}$ 骨材の反応性}

Fig. 2 に，ハイドロカルマイトの理論式に基づいた配合 $\mathrm{HCP}$ のペースト供試体に関する XRD パターンを示す.

練混ぜ直後の 0 時間においては, CA および CH 単独の ピークが確認された。一方, 練混ぜから 3 時間後におい ては，CAおよび $\mathrm{CH}$ のピーク強度が減少し，ハイドロカ ルマイト（Fig 中は HC と表記）のピークが確認された. 従って, CA 骨材を粉末状でセメントコンクリートに適用 する場合，式(1)に示した理論式じおりの水和反応が起こ ることが確認された。 すなわち, CA 骨材自身は水和反応 する材料特性を保有している.

更に，Fig. 3 に塩化物イオンが作用した場合に生成する ことが想定されるフリーデル氏塩の理論式に基づいた配 合FSPのペースト供試体に関するXRDパターンを示した. 練混ぜ直後の 0 時間では個別のピークが確認されたのに 
対し，3 時間後にはハイドロカルマイトおよびフリーデル 氏塩（Fig 中は F 塩と表記）のピークが共存している．こ れは， $\mathrm{CA}$ 粉末の水和反応として， $\mathrm{CH}$ および $\mathrm{CaCl}_{2}$ が共 存する環境下においては，ハイドロカルマイトの生成と フリーデル氏塩の生成が段階的に，あるいは，入り乱れ て進行しているためと考えられる。いずれにしても，CA 骨材自身は反応性を有しており，反応過程でセメント由 来の $\mathrm{CH}$ が供給される場合には八イドロカルマイトを生 成し，更に塩化物イオンが供給される場合にはフリーデ ル氏塩も生成し，塩化物イオンの一部を固定化し，塩害 に対する抵抗性を高める可能性が示唆された。

\section{$3 \cdot 2$ 遷移帯改質効果}

1) CA 骨材混和が水和物生成に与える影響

Fig. 4 に，CA 骨材を細骨材として用いたモルタル（以 下，CA 骨材モルタル）の XRD パターンを示す。比較と して，天然砂を用いたモルタル（以下，普通モルタル） を材齢 28 日まで水中養生した場合の XRD パターンも併 記した，本実験においては，骨材を含めたモルタル全体 を粉砕して測定試料としているため，骨材周辺に着目し た水和物の確認は出来ないが，天然砂を用いた普通モル タルでは水和物として $\mathrm{CH}$ が確認されているのに対し, $\mathrm{CA}$ 骨材を用いたモルタルでは， $\mathrm{CA}, \mathrm{CH}$ および $\mathrm{C}_{3} \mathrm{AH}_{6}$ （以下，ハイドロガーネット）が確認されている.また, ハイドロカルマイトに類似した組成の $\mathrm{C}_{4} \mathrm{AHx}$ のピークが 確認された。、すれれのモルタルでもセメント水和物であ る CH は共通しているが, それ以外の水和生成物には違い が認められている. 同定された CA は未反応のCA 骨材自 体でありが，ハイドロガーネットおよびハイドロカルマ イトに類似した $\mathrm{C}_{4} \mathrm{AHx}$ は, 式(3)および式(4)に示すように, $\mathrm{CA}$ 骨材とセメントペースト部分に存在する $\mathrm{CH}$ との反応 により生成したものと考えられる。

$$
\begin{aligned}
\mathrm{CaO} & \cdot \mathrm{Al}_{2} \mathrm{O}_{3}+2 \mathrm{Ca}(\mathrm{OH})_{2}+4 \mathrm{H}_{2} \mathrm{O} \\
& \rightarrow 3 \mathrm{CaO} \cdot \mathrm{Al}_{2} \mathrm{O}_{3} \cdot 6 \mathrm{H}_{2} \mathrm{O} \\
\mathrm{CaO} & \cdot \mathrm{Al}_{2} \mathrm{O}_{3}+3 \mathrm{Ca}(\mathrm{OH})_{2}+n \mathrm{H}_{2} \mathrm{O} \\
& \rightarrow 3 \mathrm{CaO} \cdot \mathrm{Al}_{2} \mathrm{O}_{3} \cdot \mathrm{Ca}(\mathrm{OH})_{2} \cdot(n+2) \mathrm{H}_{2} \mathrm{O}
\end{aligned}
$$

\section{2) 生成水和物の定量および変化}

XRD で確認された水和物の中で，特に CA 骨材モルタ ルで特徵がみられた水和物に着目し，ハイドロガーネッ トおよびハイドロカルマイト類似組成水和物について TG-DTA による定量を試みた，定量方法としては，材齢 28 日まで水中養生した普通モルタルと CA 骨材モルタル の TG-DTA 測定結果を比較し，異なる示差熱ピークが認 められた部分が着目した水和物の示差熱ピークであると 仮定した. Fig. 5 に材齢 28 日時点の普通モルタルと CA 骨材モルタルの TG-DTA 測定結果を示す．両者を比較す ると, $150 \sim 200^{\circ} \mathrm{C}$ 付近と, $250 \sim 350^{\circ} \mathrm{C}$ 付近のピークに異 なる傾向が認められている．既往の研究 ${ }^{6)-8)}$ によれば, 八 イドロカルマイトは $150 \sim 200^{\circ} \mathrm{C}$ 付近に，ハイドロガーネ

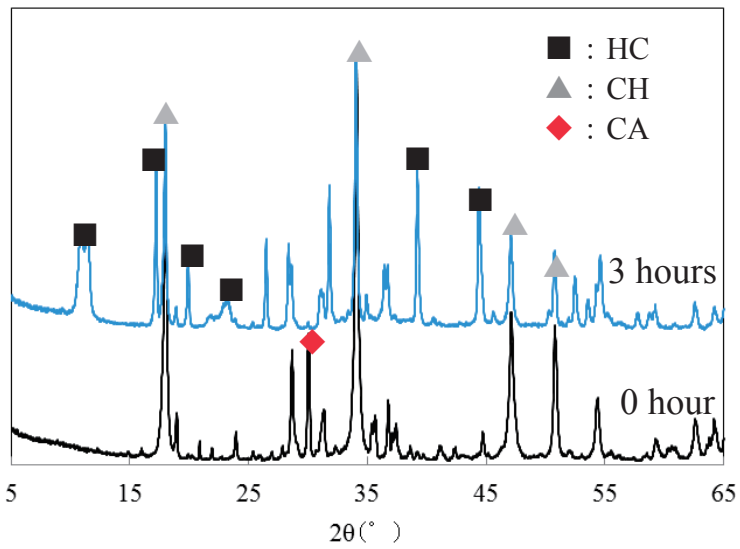

Fig.2 XRD pattern of hardened paste (No.1) .

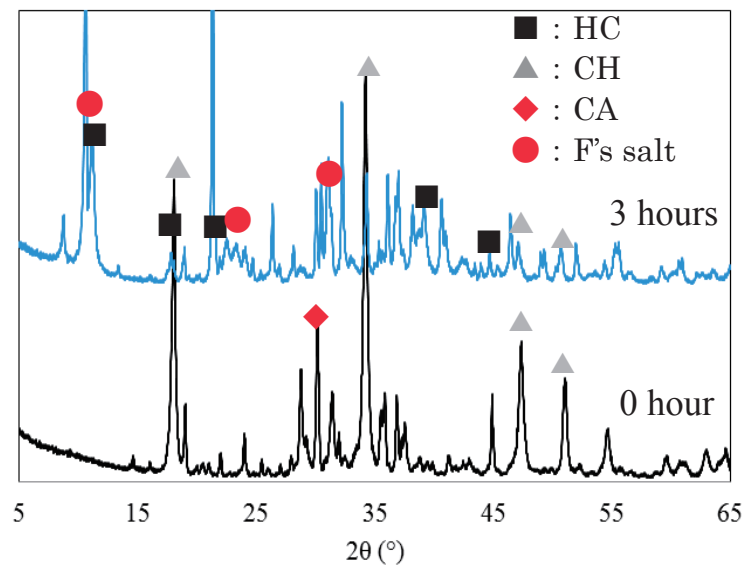

Fig.3 XRD pattern of hardened paste (No.2) .

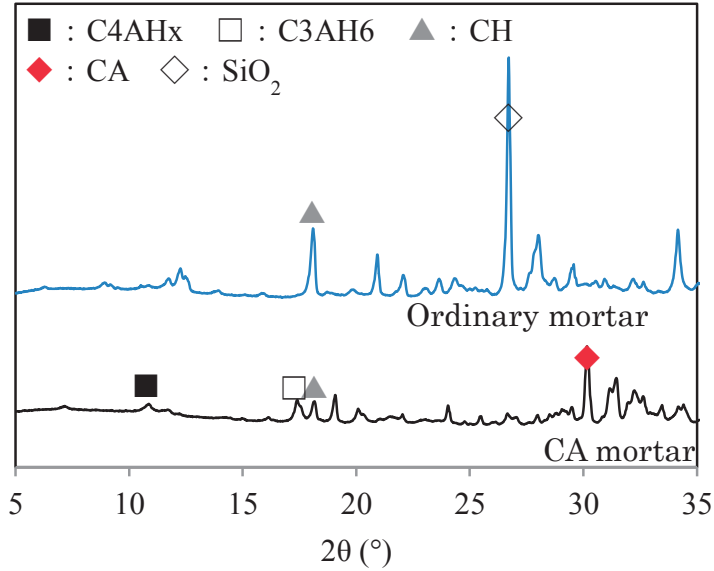

Fig. 4 XRD pattern of hardened mortar.

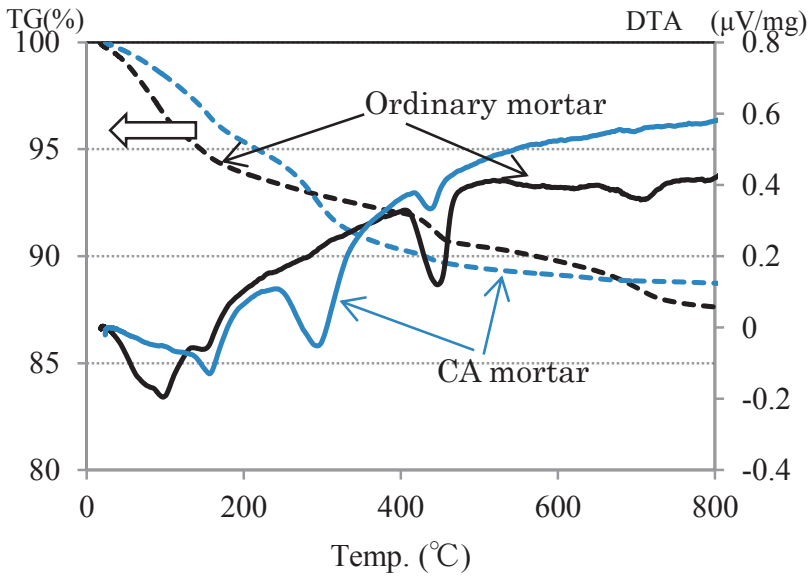

Fig.5 TG-DTA. 
ットは $250 \sim 350^{\circ} \mathrm{C}$ 付近にピークを示すとされており，今 回着目した水和物のピークとほぼ一致している. 従って, ハイドロカルマイト類似水和物については, 仮説どおり ハイドロカルマイトである可能性が高いことが示唆され た。 また，材齢の経過に伴う水和物量の変化として， Fig. 6 に普通モルタルおよび $\mathrm{CA}$ 骨材モルタルに含まれる $\mathrm{CH}$ 量の推移を, Fig. 7 に材齢 3 日, 28 日におけるハイドロカ ルマイトとハイドロガーネットの定量結果を示した。普 通モルタルは材齢の経過に伴い $\mathrm{CH}$ 量の増大が認められ るものの，CA 骨材モルタルにおいては，材齢初期段階か ら CH 量が少なく, 材齢が経過しても絶対量がほとんど増 えていないことがわかる。一方で，ハイドロカルマイト およびハイドロガーネットの含有量は材齢の経過に伴っ て増大寸る傾向が認められている。この結果より, CA 骨 材自体の水和反応としてセメントの水和によって生成さ れた CH を消費し, ハイドロカルマイトおよびハイドロガ 一ネットを生成していることが示唆された.

3) CA 骨材表面部の観察

前項までの結果において，CA 骨材自身が水和反応する 特性を保有しており，モルタル骨材として使用した場合 には特有の水和物としてハイドロカルマイトとハイドロ ガーネットを生成することが確認できている。一方で, 遷移帯の改質に関しては，これら水和物が骨材表面で生 成していることが重要である。そこで，CA 骨材モルタル 内部の骨材表面の状態を観察した. Fig. 8 に，比較となる CA 骨材単独の SEM 画像を, Fig. 9 に 5 ケ月間水中養生を 行った CA 骨材モルタルの骨材周辺の SEM 画像を示す. また，Table3 に，各種カルシウムアルミネート水和物の 化学式から算出した $\mathrm{Al}$ を 1 とした場合の理論上の各元素 のモル比割合を, Table4 にCA 骨材モルタルの元素分析で 得られた実測值を示した。CA 骨材単独では, SEM 画像 において表面部に生成物は確認されておらず，元素分析 の結果では，概ね $\mathrm{Ca}$ と $\mathrm{Al}$ のモル比が $0.042 〜 0.53$ の範囲 だった。一方，CA 骨材モルタルにおいては，骨材表面部 が多数の層状生成物で覆われていることが確認された。 本実験においては，モルタル内部の骨材周辺で代表的な 4 箇所の観察を行ったが，生成物の形状に多少の違いは認 められるものの，いずれの箇所においても層状の生成物 が確認されている.また, Table4 にまとめた各種元素の モル比の実測值と Table3 との対比から，骨材表面部で確 認された水和物はハイドロカルマイトとハイドロガーネ ットの理論值と非常に近い值を示しているため, CA 骨材 表面はこれら水和物で覆われているものと考えられる.

従って，XRD および TG-DTA で確認された水和物は CA 骨材の表面部が水和反応したことによって生成されたも のであると考えられる.

Table5 に，各種水和物の密度を示した．この密度を元 に水和物の体積変化を算出すると, 八イドロカルマイト を生成する場合の固相の体積増加率は $182 \%$ ，八イドロガ 一ネットを生成する場合に体積増加率は $125 \%$ となり，こ れは緻密化することを意味している。前述のとおり，CA

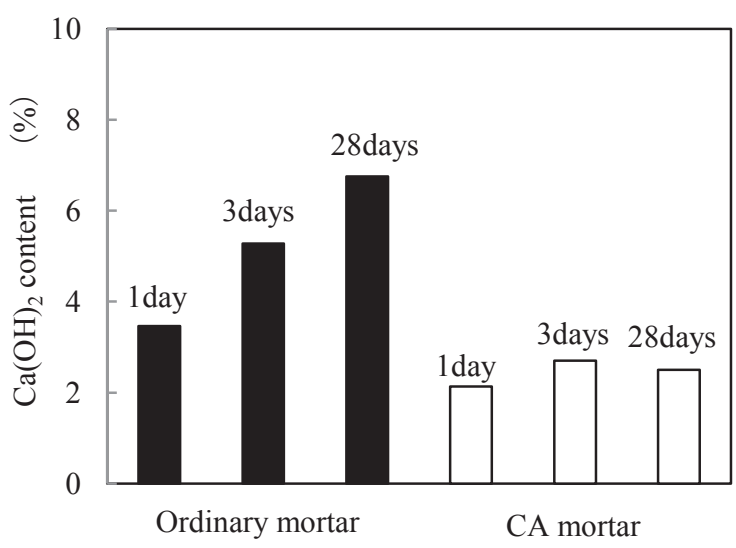

Fig.6 Content of $\mathrm{CH}$.

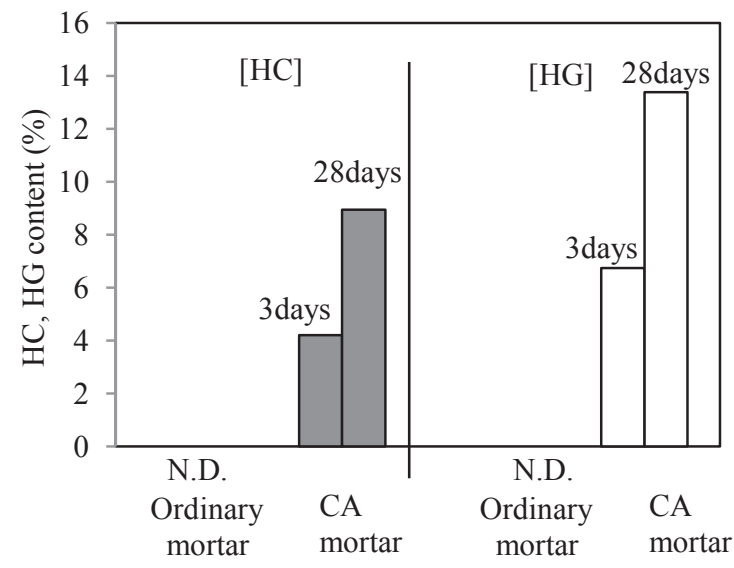

Fig.7 Content of HC and HG.

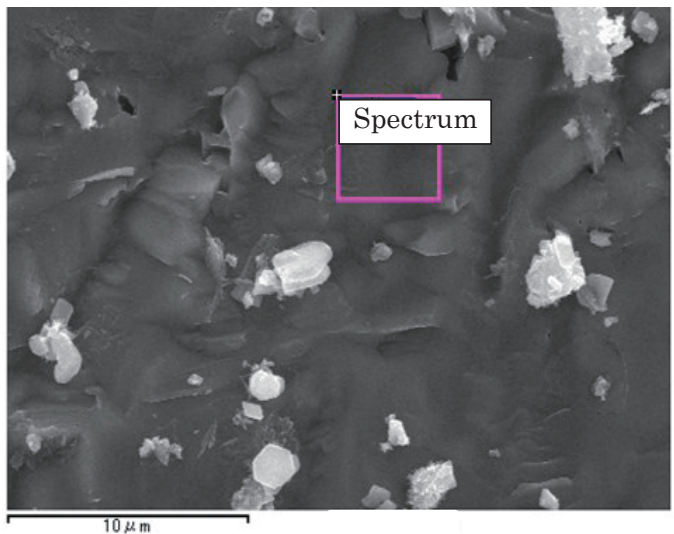

Fig.8 SEM image of CA sand.

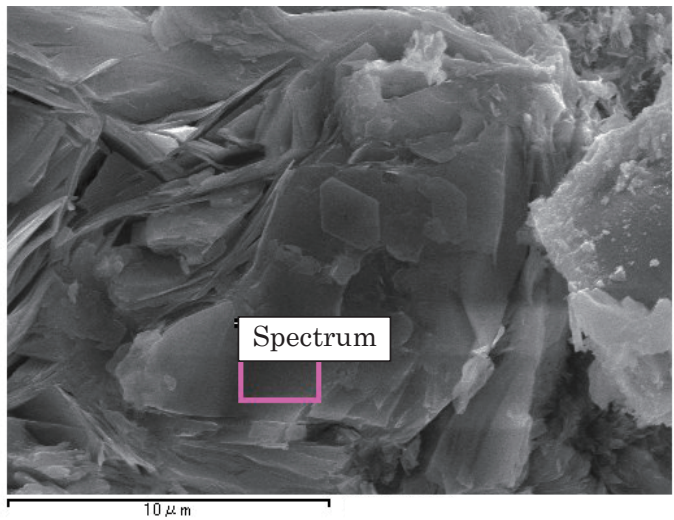

Fig.9 SEM image of CA sand surface after water curing. 
骨材モルタルの骨材表面部付近においてこれらの水和物 生成が確認されていることから，CA 骨材を使用すること で遷移帯の空隙部を小さくできるなど，脆弱層の改質効 果が得られる可能性が示唆された.

4) 塩化物イオンの作用による影響

Fig. 10 に, 塩水浸漬後のモルタル内部への塩化物イオ ン浸透状況を示す。これより，普通モルタルにおいては モルタル内部まで塩化物イオンが完全に浸透しているの に対し, 同一条件下において CA 骨材モルタルでは浸透が 大幅に抑制されていることが確認された。そこで，この 機構を解明することを目的に，塩水浸漬後の供試体につ いて XRD，骨材周辺の SEM 観察および元素分析を行っ た。なお, SEM 観察に関しては, EPMA 画像解析によっ て塩化物イオンが確実に浸透していることが確認された 箇所での骨材表面部の水和物の観察を行っている. Fig. 11 にXRD 測定結果の拡大図を, Fig. 12 にSEM 画像を示す.

XRD 測定結果より，塩水浸漬前には，水和物として八 イドロカルマイトとハイドロガーネットが確認されてい たが，塩水浸漬後には，ハイドロカルマイトのピークは 確認されず，代わりにフリーデル氏塩が生成しているこ とを確認した. また, SEM 画像より, 骨材周辺が数多く の六角板状の結晶で覆われていることが確認され，既往 の研究で報告されているフリーデル氏塩の結晶形態と類 似している．また，EDS による元素分析結果から，SEM 観察箇所の $\mathrm{Ca} / \mathrm{Al}$ モル比は $1.99, \mathrm{Cl} / \mathrm{Al}$ モル比は 0.63 と比 較的 Table3 に併記したフリーデル氏塩の理論上のモル比 と近い值を示すことを確認した。従って，骨材周辺に生 成したハイドロカルマイトが, 塩化物イオンを固定化し, フリーデル氏塩へと変化したことが示唆された.

一方で，CA 骨材モルタルの骨材周辺部において，フリ 一デル氏塩に類似した $\mathrm{Ca} / \mathrm{Al}$ モル比が 2.0 付近の箇所の他 に, $\mathrm{Ca} / \mathrm{Al}$ モル比が 1.5 前後の箇所や, ほとんど $\mathrm{Al}$ のみの 箇所が確認された。 そこで，EPMA 画像解析により，各 元素の濃度分布について検証を行った. Fig. 13 に, CA 骨 材モルタルの骨材周辺を拡大し, 且つ $\mathrm{Ca} / \mathrm{Al}$ モル比をマッ ピングした画像を示す. CA 骨材界面付近における $\mathrm{Ca} / \mathrm{Al}$ モル比は一定ではないが，おおよそ $\mathrm{Ca} / \mathrm{Al}$ モル比が 1.5〜 2.0 の分布となっており, 部分的に $\mathrm{Ca} / \mathrm{Al}$ モル比が 2.0 よ りも高い箇所や 1.0 よりも低い箇所が確認できる.これよ り，CA 骨材自身の反応としてハイドロカルマイトやフリ 一デル氏塩を生成する一方で, ハイドロガーネットや $\mathrm{AH}_{3}$ などの水和物も骨材界面付近には存在し, それらが共存 しているものと推察された．従って，CA骨材の界面が全 てフリーデル氏塩として塩化物イオンを固定化するとは 言い難いが，骨材として用いることでペースト部よりも 硬化体内部の占有面積が多くなるため, 仮に一つひとつ の骨材周辺で固定化できる塩化物イオン量が少なかった としても，モルタル表面から内部に至るまでに塩化物イ オンを捕らえる網が張り巡らされているとも言える。こ のことから，CA 骨材はセメントコンクリートの弱点の一 つである遷移帯を水和物の生成によって緻密化して改質
Table3 Molar ratio of hydrates (theoretical value).

\begin{tabular}{|l|l|l|l|l|}
\hline & $\mathrm{Ca}$ & $\mathrm{Al}$ & $\mathrm{O}$ & $\mathrm{Cl}$ \\
\hline $\begin{array}{l}3 \mathrm{CaO} \cdot \mathrm{Al}_{2} \mathrm{O}_{3} \cdot \mathrm{Ca}(\mathrm{OH})_{2} \cdot 12 \mathrm{H}_{2} \mathrm{O} \\
\left(\mathrm{C}_{4} \mathrm{AH}_{13}: \mathrm{HC}\right)\end{array}$ & 2 & 1 & 10 & - \\
\hline $\mathrm{CaO} \cdot \mathrm{Al}_{2} \mathrm{O}_{3} \cdot \mathrm{H}_{2} \mathrm{O}$ & 0.5 & 1 & 2.5 & - \\
\hline $\mathrm{CaO} \cdot \mathrm{Al}_{2} \mathrm{O}_{3} \cdot 10 \mathrm{H}_{2} \mathrm{O}$ & 0.5 & 1 & 7 & - \\
\hline $\mathrm{CaO} \cdot \mathrm{Al}_{2} \mathrm{O}_{3} \cdot 8 \mathrm{H}_{2} \mathrm{O}$ & 1 & 1 & 3 & - \\
\hline $\left.\begin{array}{l}3 \mathrm{CaO} \cdot \mathrm{Al}_{2} \mathrm{O}_{3} \cdot 6 \mathrm{H}_{2} \mathrm{O} \\
\left(\mathrm{C}_{3} \mathrm{AH}\right.\end{array} \mathrm{HG}^{\mathrm{H}}\right)$ & 1.5 & 1 & 6 & - \\
\hline $\begin{array}{l}3 \mathrm{CaO} \cdot \mathrm{Al}_{2} \mathrm{O}_{3} \cdot \mathrm{CaCl}_{2} \cdot 10 \mathrm{H}_{2} \mathrm{O} \\
(\mathrm{F} \text { 's salt })\end{array}$ & 2 & 1 & 8 & 1 \\
\hline
\end{tabular}

Table4 Molar ratio of hydrates (measured value).

\begin{tabular}{|c|c|c|}
\hline \multirow{2}{*}{ Position of observation } & \multicolumn{2}{|c|}{ Molar ratio } \\
\cline { 2 - 3 } & $\mathrm{Ca} / \mathrm{Al}$ & $\mathrm{O} / \mathrm{Al}$ \\
\hline Point-1 & 2.06 & 7.02 \\
\hline Point-2 & 1.53 & 7.15 \\
\hline Point-3 & 1.38 & 12.67 \\
\hline Point-4 & 1.59 & 10.34 \\
\hline
\end{tabular}

Table5 Density of hydrates.

\begin{tabular}{|c|c|}
\hline & Density $\left(\mathrm{g} / \mathrm{cm}^{3}\right)$ \\
\hline CA & 2.95 \\
\hline CH & 2.24 \\
\hline HC & 2.02 \\
\hline HG & 2.52 \\
\hline F's salt & 2.09 \\
\hline
\end{tabular}

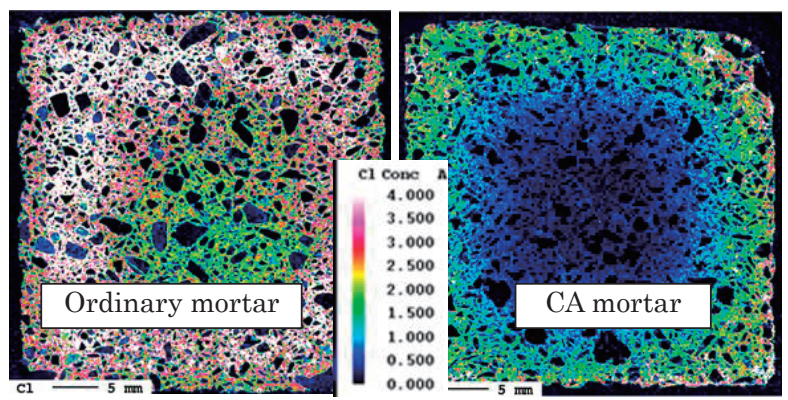

Fig.10 Chloride ion penetration depth.

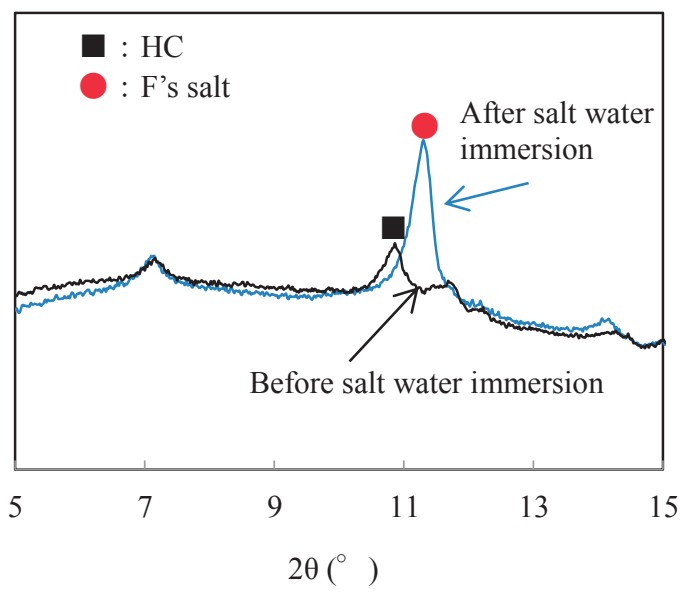

Fig. 11 XRD pattern. 
する可能性があり, さらに塩化物イオンが作用する環境 下では，塩化物イオンの移動経路として最も弱点となる 遷移帯で塩化物イオンを固定化する働きも期待できるこ とから, 塩害抵抗性を高めるコンクリート技術として有 用となる可能性がある。

\section{4 結 言}

塩化物イオンの浸透抑制効果が期待できるカルシウム アルミネートを骨材として使用した場合の遷移帯の改質 効果とその機構について検討し，以下の結論を得た.

1 ） ハイドロカルマイトおよびフリーデル氏塩の理論化 学式に基づいたペースト試験の結果より，CA 骨材自身は 水和反応性を有しており, 反応過程でセメント由来の $\mathrm{CH}$ が供給される場合にはハイドロカルマイトを生成する.

2 ）更に塩化物イオンが供給される場合にはフリーデル 氏塩を生成し，塩化物イオンを固定化する。

3) CA 骨材をモルタル用の細骨材として使用した場合で も，骨材表面部で水和反応が起こり，八イドロカルマイ トやハイドロガーネットを生成することが確認された。 また，これら反応は固相の体積変化という観点からは緻 密化反応であり，遷移帯の空隙部を埋める，もしくは空 隙を小さくする効果をもたらす.

4) CA 骨材モルタルは，普通モルタルと比較して高い塩 化物イオンの浸透抑制効果を有する.

5 ）塩水浸漬後の CA 骨材モルタルにおいて，XRD では フリーデル氏塩の生成が確認された。また、SEM 画像に おいてもモルタル内部の骨材周辺にフリーデル氏塩と類 似した水和物が観察され，EDS による元素分析でもフリ ーデル氏塩と類似した $\mathrm{Ca} / \mathrm{Al}$ モル比であることが確認さ れた。

5 ) 塩水浸漬後の CA 骨材モルタル内部にある CA 骨材表 面には, $\mathrm{Ca} / \mathrm{Al}$ モル比が 1.5 2.0 の水和物が多く混在して いることが確認された。

1) M. Morioka, "Cement additive and Cement composition”, JP2005-104828 (2005).

2) K. Tabara, K. Yamamoto, K. Ahida and M. Morioka, "Fixation ability of chloride ion by hardened cement added with $\mathrm{CaO} \cdot 2 \mathrm{Al}_{2} \mathrm{O}_{3}$ ", Cement science and concrete technology, Vol. 64, pp. 428-434 (2010).

3) K. Tabara, K. Miyaguchi, M. Morioka and K. Takewaka, "Hydration behavior and fixation ability of chloride ion by a variety of kinds of hardened cements added with $\mathrm{CaO} \cdot 2 \mathrm{Al}_{2} \mathrm{O}_{3}$ ”, Cement science and concrete technology, Vol. 65, pp. 427-434 (2011).

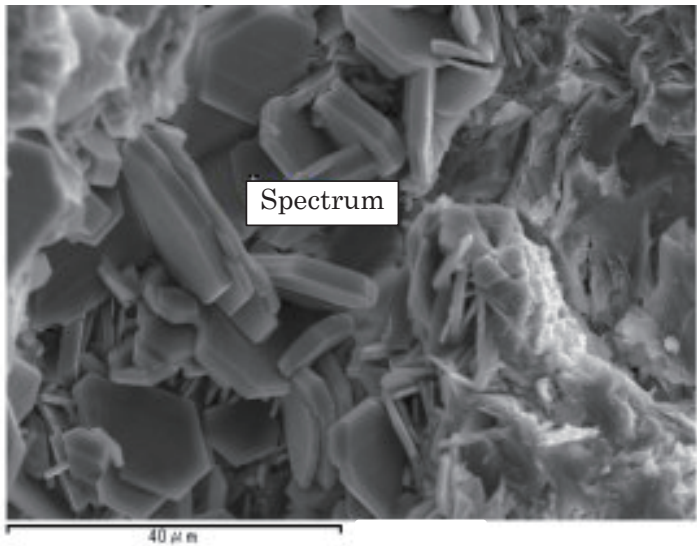

Fig.12 SEM image of CA sand surface.

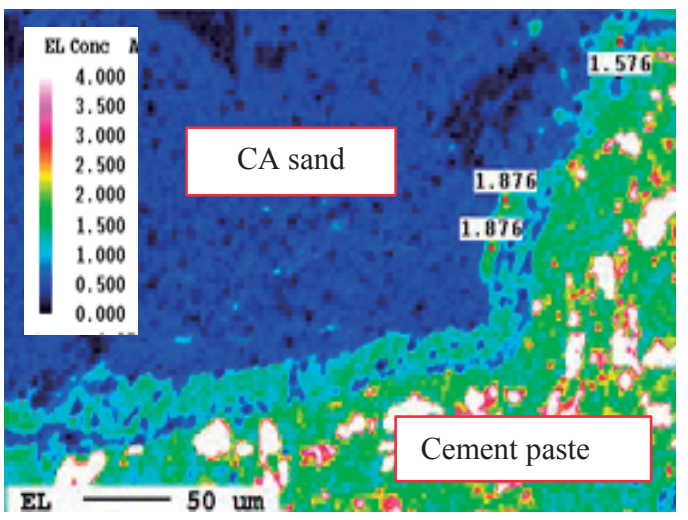

Fig. $13 \mathrm{Ca} / \mathrm{Al}$ molar ratio distribution of CA mortar.

4) T. Ito, S. Ito, M. Morioka and T. Iyoda, "Evaluation of salt tolerance of low heat Portland cement using with chloride ions immobilized material and expansive additive", The annual meeting Cement and Concrete Engineering, Vol. 69, pp. 236-237 (2015).

5) Y. Kato, T. Uomoto. Niimiya and T. Miyagawa, , "Modeling of effective diffusion coefficient of substances in concrete considering spatial properties of composite materials", Journal of Advanced Concrete Technolog, Vol. 3 No. 2 pp. 241-251 (2005)

6) J. Plank and Friedrich von Hoessle, "Zeitschrift für Anorganische und Allgemeine Chemie“, zaac . 201000001. R1

7) M. Anson, J. M. Ko and E. S. S. Lam;Advances in Building Technology, Vol. 2002, pp-883

8) H. Tanaka, K. Murakami and M. Sato, "Studies on hydration of calcium aluminoferrite phase and its glass in portland cement clinker” , Journal of the Ceramic Society of Japan, Vol. 74, No. 845, pp20-27 (1966). 